\title{
The Adoption of Neo-Confucianism in Discussing Legitimacy Dispute
}

\author{
Puning Liu ${ }^{1}$ \\ ${ }^{1}$ Leiden University, Netherlands \\ Correspondent: Puning Liu, Leiden University, Netherlands. E-mail: alexander8364@hotmail.com
}

Received: October 26, 2017

Accepted: November 30, 2016

Online Published: December 8, 2017

doi:10.5539/ach.v10n1p43

URL: http://dx.doi.org/10.5539/ach.v10n1p43

\section{Introduction}

Lipset (1960) denotes legitimacy as "the capacity of the system to engender and maintain the belief that the existing political institutions are the most appropriate ones for the society." All political powers, including Chinese dynasties in history, needed legitimacy to ensure their governance. In general, Western thinkers who discuss political legitimacy could be identified into two groups (Habermas, 1979). The "empiricists", likes Max Weber, studies legitimacy in an empirical method, focusing on the types, constitutions, functions, and evolutions of legitimacy. The second group consists of "normativists", such as Plato and John Rawls, who tend to base legitimacy on various normative values such as justice or democracy. Pre-modern Chinese views on political legitimacy have the similar approaches like west. The first one pays attention to different empirical factors of legitimacy. For instance, the pre-Qin philosopher Zou Yan 鄒衍 (305-240 BCE), and Western Han thinker Liu Xin 劉歆 (50 BCE-23 CE) view a dynasty's legitimate by its adoption of rightful dynastic phase (Wang 2006). The Song Dynasty (960-1279) historian Ouyang Xiu 歐陽修 (1007-1072) argues that the just position and the unification of China make a legitimate dynasty (Rao 1996). The second approach bases legitimacy on normative values. For example, Confucius 孔子 (551-479 BCE) indicates that the rightfulness of a ruler relies on his properly practicing both "benevolence" (ren 仁), and "rites" ( $l i$ 禮). Many present scholars give us their studies on the legitimacy in Chinese history. For instance, Rao Zong (1996) provides the general overviews of legitimacy in the Chinese tradition, with an extensive collection of relevant primary sources. Hou Deren (2009) introduces most relevant present-day Chinese studies on that issue. For English readers, general studies of traditional Chinese views on legitimacy can be found in the writings of Hok-lam Chan (1984) and Richard Davis (1983).

Nevertheless, it is notable that the question of legitimacy became pressing from the 13th century onwards in China, when China was ruled by non-Chinese ruling houses, such as the Yuan Dynasty 元 (1272-1368) and Qing Dynasty 清朝 (1889-1912). Scholars during that period showed a great interest in discussing the question of what makes a legitimate ruler of China. In general, these scholars approached that question in two ways; they introduced the prevailing Neo-Confucianism to define the virtuous rule as the principal value of legitimacy (Bol, 2009), or they defined a Chinese ruled dynasty as legitimate. To reveal these scholars' distinct views on legitimacy, this paper investigates two of them, the Yuan literatus Yang Weizhen 楊維楨 (1296-1370) and the Ming (1368-1644) scholar-official Fang Xiaoru 方孝孺 (1357-1402). For English readers, only Richard Davis (1983) gives a brief introduction on Yang Weizhen's views on legitimacy. Few studies focus on Fang Xiaoru's relevant views. Following the text analysis way, this article proves that Yang Weizhen and Fang Xiaoru acted as two representatives of scholars in the late imperial China. Both of them adopted Neo-Confucianism to discuss legitimacy, viewing the discussion of legitimacy as a moral evaluation of the dynasty and monarch. They also shared the idea that Chinese ruled dynasty should be viewed as legitimate.

\section{Yang Weizhen's Views on Legitimacy}

In 1296, Yang Weizhen was born in a Han-Chinese scholar family in the south China. In 1327, he earned the "Metropolitan Graduate" (jingshi 進士) degree and served as a regional governor before he resigned from the civil service. Thereafter, Yang Weizhen devoted himself to scholarly pursuits and gradually became a distinguished scholar (Goodrich eds, 1976).

Yang Weizhen's discussion about the legitimacy had a direct relation to the compilation of the official chronicles of three coexisting dynasties prior to the Yuan Dynasty, the Khitan Liao (907-1125), the Jurchen Jin (1115-1234) and the Song Dynasty (960-1279). For the newly-established dynasty in ancient China, the compilation of the official chronicles for its previous dynasty serves as an effective way to support this dynasty's legitimacy in return. The Yuan Dynasty did the same. In 1261, the Yuan court had organized its scholars to compile the official 
chronicle for these three dynasties. However, scholars encountered a knotty problem since all the three dynasties declared themselves as the exclusive legitimate regime (Davis, 1983). Since scholars failed to reach the consensus in solving the legitimacy problem, the first two compilations failed. In 1343, the Yuan court initiated the third compilation and summoned some influential scholars, including Yang Weizhen, to assist that work. Yang Weizhen participated into the compilation and soon submitted an essay named Zhengtong bian正統辨 (Polemic on Legitimate Succession) to express his idea about the Khitan Liao, Jurchen Jin and Song Dynasty legitimacy issue. This essay is included in Rao's book (Rao, 1996). This essay firstly discusses the origin of the legitimacy and then argues that the Song Dynasty is the exclusive legitimate predecessor of the Yuan Dynasty.

\subsection{The Origin of Legitimacy}

Form the Yuan Dynasty onwards, the Neo-Confucianism served as the national ideology in China (Bol, 2009). In their discussing about legitimacy, a large proportion of scholars during this period had adopted the Neo-Confucianism. Generally, this ideology argues the abiding of moral rules is the crucial criterion of the political legitimacy. Yang Weizhen follows the same view. His essay begins with a study about the origin of the legitimacy. Introducing the Neo-Confucian doctrine, his essay says "the lineage of legitimate or illegitimate [dynasty] for thousand years has genuinely grown out from the consensus in people's minds about right and wrong." (Davis, 1983). Yang's essay stresses that the study of legitimacy should focus on highlighting Confucian moral principles.

As [legitimate] succession is the product of a consensus between heaven's mandate and men's minds, then how can the series of successions since the Three Dynasties period recklessly be attributed to man [alone]? For this reason, the great import of legitimate succession was set forth in the Classic of the Sage to sustain ethical norms and bonds for countless ages. (Rao, 1996)

The Mandate of Heaven is one of the most significant legitimacy resources in traditional Chinese context. As Allen (1981) describes, "heaven's command determined the ruler. Heaven normally transferred its mandate hereditarily, but if a king violated the principles of heaven, he lost his moral imperative, and the right to rule was bestowed on another." Therefore, in Yang Weizhen's eyes, legitimacy, rather than being a private property of rulers, originates from the combination of the Mandate of Heaven and moral principles. He also argues that the promotion of moral norms is the significance of the study of legitimacy. To echo that idea, Yang's essay gives a review to the Chunqiu 春秋 (the Spring and Autumn Annals), or one of the Confucian Classics of the sage mentioned above.

The Chunqiu, a work allegedly attributed to Confucius, conveys this master's idea about legitimacy as many Confucian scholars believed. As Yang's essay describes, this annals set the Zhou Dynasty 周朝 (1045-256 BCE) as the exclusive legitimate since Confucius believes this dynasty completely meets the combination of the Mandate of Heaven and moral principles. On the contrary, the Chunqiu greatly depreciates and criticizes some contemporaneous feudal states, such as the Qi state 齊國 (around the $11^{\text {th }}$ century BCE-221 BCE), the Chu state 楚國 (around the $11^{\text {th }}$ century BCE-223 BCE) and other states, for their challenging the Zhou's legitimate status. The contemporaneous Zhou was too weak to control its vassals thereby it only remained as a nominal lord. Many powerful feudal lords stood in open defiance of the Zhou court and assumed illicit titles, such as wang 王 (king) or $d i$ 帝 (emperor). Yang's (Davis, 1983) essay points out that even though these feudal states had a larger territory and a mightier power compared with the contemporaneous Zhou court, the Chunqiu still does not view them as legitimate. The larger territory and the mightier power cannot make a legitimate regime, as Yang Weizhen concludes (Rao, 1996).

Yang's essay continues to mention that the greatest Neo-Confucian master, Zhu Xi 朱喜 (1130-1200), also supports these aforementioned ideas and therefore sets the Shu Han 蜀漢 (221-263) - but not this dynasty's power rival the Cao Wei 曹魏 (220-265) — as legitimate ruler of entire China. Moreover, Yang's essay criticizes the previous scholar, Chen Shou 陳壽 (233-297), for his violating that aforementioned idea and set the Cao Wei as legitimate in his famous Sanguozhi (三國志).

\subsection{The Legitimacy Dispute Among the Liao, Jin and Song.}

Yang Weizhen specifically discusses the Khitan Liao, Jurchen Jin and Song Dynasty's legitimacy dispute in his essay.

As Yang's essay describes, the legitimate rulership transferred through the Northern Song to the Southern Song, and then to the Yuan Dynasty, entirely bypassing the Khitan Liao and Jurchen Jin Dynasty (Davis, 1983). The Song Dynasty served as the exclusively rightful predecessor of the Yuan Dynasty. It is easy to predict Yang 
Weizhen's support to the Song Dynasty. Although he served the Yuan Dynasty, Yang Weizhen is a scholar whose bond with Han-Chinese culture is deep-seated. As Davis (1983) describes, "politically, his loyalty to the Yuan government was undivided; but intellectually and culturally, Chinese traditions were quite compelling."

Yang's essay provides two reasons to defend the Song's legitimate status. Firstly, it defines both the Khitan Liao and Jurchen Jin Dynasty as illegitimate rulers of China. These two dynasties, as this essay describes, are "barbarian" regimes with inferior culture. Yang Weizhen has some racism views and he describes, "in the beginning [of the Khitan Liao], [their habits of] allowing a corpse to decompose [with- out proper burial] and of wearing pig and hog [skins] on the head and body were so ridiculous and bizarre that people of the Middle Kingdom would not [so much as] speak of them (Davis, 1983)." He snubs that these two dynasties were the frontier "barbarian" in origin and established their mighty rulership by taking advantage of the falling of the central realm regimes (the Tang 唐 朝 (618-907) and the Northern Song respectively). Yang Weizhen indicates that both dynasties are illegitimate for not possessing the Mandate of Heaven and adopting the moral principles.

Secondly, Yang Weizhen argues that the Song Dynasty is legitimate. The Northern Song united the central realm, succeeded the legitimate rulership from the Tang Dynasty, and ruled its people beneficently. The Southern Song Dynasty succeeded the legitimate rule and protected its people from the warfare for a long period (Rao, 1996). Yang's essay concludes that the Yuan Dynasty succeed the legitimate rule when it conquered the Southern Song and united China.

In conclusion, by introducing Neo-Confucianism to the debate, Yang Weizhen argues that the combination of the Mandate of Heaven and moral principles is the origin of political legitimacy. He also introduces the Chunqiu to strengthen that idea. Yang Weizhen further supports the Song Dynasty's exclusive legitimacy, arguing the Yuan Dynasty succeed legitimate status from that dynasty.

\section{Fang Xiaoru's Views on Legitimacy}

Born in 1357, Fang Xiaoru was a well-acknowledged writer of literature during his time and once served as “Hanlin Academician" (hanlin xueshi 翰林學士) (Goodrich, 1976). However, in 1402 when Zhu Di 朱棣 (1360-1424), the future Yongle Emperor 永樂帝 (r. 1402-1424), usurped the throne, Fang Xiaoru was executed for his resolute criticism of that usurpation. Fang Xiaoru's discussions on legitimacy can be found in the essay “Shitong” 釋統 (Interpretation of Succession) (Fang, 2000). In this essay, Fang Xiaoru first introduces Heavenly principles, the key notion in the Neo-Confucianism, to describe legitimacy. He also studies types of dynastic succession, arguing for "rightful" and "variable" succession.

\subsection{Heavenly Principles and Legitimacy}

In the first section of his essay, Fang asks whether we can equate brutal and short-lived dynasties, such as the Qin 秦朝 (221-206 BCE), with glorious and long-lasting ones, such as the Zhou and Han 漢朝 (202 BCE-220 CE). This could be possible, since many previous scholars pointed out that all these dynasties had different pieces of evidence to support their legitimacy, such as the unification of China and the adoption of the rightful dynastic phase. However, Fang describes the idea as ridiculous. He argues that any discussion about legitimacy should be based on "Heavenly principles", the core notion of Neo-Confucianism, which, as he indicates, could enable one to distinguish illegitimate dynasties from legitimate ones. Heavenly principle, as Antonio Cua (2003) points out, "is often used to convey the Neo-Confucian notion of ren, the ideal of the universe, as a moral community." Fang provides some clues about how Heavenly principles could be used to discuss legitimacy (Fang, 2000).

As for the discussion about legitimacy, what does it take to be successful? If we add the label [legitimate] to [a regime] because it rules All under Heaven, then why does that regime not add the label by itself, since it [is powerful enough to] rule All under Heaven? However, because we wish to use this [discussion of legitimacy] to praise or criticize [dynasties in history], to bring order to the major distinctions [among various social classes], to explain the righteous relationship between rulers and officials, to shed light on the difference between benevolence and tyranny, to include Chinese and exclude Barbarians, and to support Heavenly principles and punish the malpractice of man, it should not be left undiscussed.

It is evident that rather than citing a dynasty's dominance of China to support its legitimacy, Fang believes the discussion of legitimacy should represent a moral evaluation of a dynasty, highlight social orders, distinguish between benevolent rule and tyranny, and support the dichotomy between "barbarian" (what ancient Chinese called all the other non-Chinese) and "Chinese". All these factors could be viewed as specific terms of Heavenly 
principles, which generally represent various Confucian moral principles, such as righteousness and benevolence. Fang also views the dichotomy between "barbarian" and "Chinese" as a part of Heavenly principles.

\subsection{What is the Rightful Dynastic Succession}

Fang argues for a twofold classification of dynastic succession. The first type is "rightful succession" (zhengtong 正統), which was accomplished by two kinds of legitimate dynasties (Fang, 2000). The superior kind included the three ancient Chinese dynasties: Xia, Shang, and Zhou, which were completely legitimate due to their absolute obedience to Heavenly principles. The inferior kind consisted of three dynasties: Han, Tang, and Song, which, while not equal to the superior dynasties, had practiced some manner of virtuous rule and were therefore included. Fang argues that the Mandate of Heaven, or political legitimacy, was transferred between these six dynasties, which constituted the "rightful succession" category.

The second type of dynastic succession is "variable succession" (biantong 變統) which was practiced by three classes of illegitimate dynasties that violated Heavenly principles. These three classes, as Fang points out, are dynasties founded by usurpation, such as the Cao Wei and the Southern Dynasties 南朝 (420-589); those ruled by tyrants, such as the Qin and Sui; and those governed by barbarians or females, such as the Yuan, and the Wu Zhou 武周朝 (690-705). Fang specifically points out that the usurping monarch violated the moral norms between lord and subject by betraying and replacing their lords to establish their own rules. He also says that a female ruler could not be legitimate since she ruled males, which violated the moral principles regarding male and female.

It is notable to see that Fang specifically discusses why a barbarian dynasty is illegitimate by referring to the ethnic criterion, which set a legitimate rule as a Chinese-ruled state that inherits Chinese culture and occupies China. He accuses rulers of the "barbarian" dynasties, such as the Yuan, of practicing inferior "barbaric" culture and having insufficient consciences to allow them to follow Heavenly principles (Fang, 2000). Fang describes barbarians as "beasts". His analogy is that of a child who would try to kill a beast even if that beast presented itself as human, indicating that a barbarian ruler could not be viewed as civilized and legitimate even if he adopted Chinese culture.

In short, Fang appeals to Heavenly principles to discuss legitimacy and views a legitimate dynasty as one that embodies the Confucian values of righteousness and benevolence. He provides a classification of dynasties, in terms of which some dynasties are determined to be illegitimate because they were established through usurpation, and the non-Chinese dynasties as illegitimate because of their "barbarian" rulers.

\section{Conclusion}

In the mid-18th century, Qing Dynasty scholars were gathered to compile the largest collection of books in Chinese history, the Siku Quanshu 四庫全書 (Complete Library in Four Sections). Scholars soon encountered a troublesome question relating to Yang Weizhen's essay, "Polemic on Legitimate Succession". The Qing scholars could be in favor of this essay because, similar to Yang Weizhen, they also viewed their dynasty, which had the similar non-Han Chinese rulers like the Yuan Dynasty, as legitimate. However, Yang's essay also fiercely denies the legitimate status for all the other non-Han Chinese dynasties, especially the Jurchen Jin Dynasty which was seen as the ancestral regime of the Qing Dynasty at that time. The ruling class of the Qing Dynasty, the Manchu people is a close descendent of Jurchen people. Therefore, the Manchu people originally named their regime as Late Jin 後金. Qing scholars therefore suggested excluding Yang's essay from the Siku Quanshu.

Interestingly, the Qianlong Emperor 乾隆帝 (1735-1795) showed firm support to Yang Weizhen's essay. In an imperial edict to his officials, he fully adopts Yang Weizhen's idea to discuss legitimacy. He not only reiterates Yang's essay, which says the combination of the Mandate of Heaven and people's moral principles are the origin of legitimacy, but also stresses that his dynasty is the legitimate successor of the Ming Dynasty, not the Jurchen Jin. The Qianlong Emperor also provides his view on the legitimacy issue, arguing that the Song Dynasty — rather than the Khitan Liao, and the Jurchen Jin - were legitimate. The Qianlong Emperor concludes by describing his dynasty as the most legitimate one in China's history since it had completely met all criteria of legitimacy, such as the possession of the Mandate of Heaven, the adoption of the moral principle in politics, and the dominance over All under Heaven.

The above case indicates that Neo-Confucianism, adopted by Yang Weizhen and Fang Xiaoru, played a dominant role in discussing legitimacy in late Imperial China. In fact, many scholars, such as the Ming scholar Xie Bi 謝陛 (around the $16^{\text {th }}$ century) and two Qing scholars, Wei Xi 魏禧 (1624-1681) and Gan Jing 甘京 (around the middle of $17^{\text {th }}$ century) all second views from Yang Weizhen and Fang Xiaoru to discuss political legitimacy (Rao 1996). However, since the end of the Ming Dynasty, some scholars started to demonstrate previous views of legitimacy. Wang Fuzhi 王夫之 (1619-1692) argued that most conventional legitimacy resources, like the unification of China and succession of legitimate dynasties, contradict historical reality (Rao, 1996). Liang Qichao 
梁啟超 (1873-1929) furthered Wang Fuzhi's critiques, denying the validity of virtually all traditional Chinese legitimacy resources, such as the occupation of China, the long-reigning period, and a Chinese rule. Liang Qichao introduced Western ideas and argued democracy and constitutionalism justify legitimacy. Some present-day scholars believe Liang Qichao's critiques could mark the end of traditional Chinese views of legitimacy (Rao, 1996). In 1912, the Chinese imperial period ended. On February $12^{\text {th }}$, the Qing court issued its last imperial edict, announcing its abdication, which declared that the Mandate of Heaven began to support a new-born state: the Republic of China (ROC). The Republic of China, however, cherished a distinct idea. On January 1st of 1912 when its first president Sun Yat-sen 孫中山 (1866-1925) proclaimed the establishment of that state, he announced that the ROC would base its legitimacy on the public will.

\section{Reference}

Allen, S. (1981). The Heir and the Sage: Dynastic Legend in Early China. San Francisco: Chinese Materials Center.

Bol, P. K. (2009). Neo-Confucianism in History. Cambridge: Harvard University Press.

Cua, A. S. (Eds.). (2003). Encyclopedia of Chinese philosophy. New York; London: Routledge.

Davis, R. L. (1983). Historiography as Politics in Yang Wei-chen's Polemic on Legitimate Succession. T'oung Pao, 69, 33-72. https://doi.org/ 10.1163/156853283X00045

Fang, X. R. 方孝穤 (2000). Xunzhizhai ji 遜志齋集. Ningbo 寧波: Ningbo chubanshe 寧波出版社.

Goodrich, L. C., \& Fang, C. Y. (Eds.). (1976). Dictionary of Ming Biography, 1368-1644. New York: Columbia University Press.

Habermas, J. (1979). Communication and the Evolution of Society (Thomas McCarthy, Trans.). Boston: Beacon Press.

Hok-lam Chan (1984). Legitimation in Imperial China: Discussions under the Jurchen-Chin Dynasty (1115-1234). Seattle: University of Washington Press.

Hou, D. R. 侯德仁 (2009). Jin sanshi nianlai de zhongguo shixue zhengtonglun yanjiu zongshu 近三十年來的 中國史學正統論研究綜述。Lanzhou xuekan 蘭州學 刊，7, 203-206. https://doi.org/10.3969/j.issn.1005-3492.2009.07.055

Lipset, S. M. (1960). Political Man: The social basis of modern politics. NY: Doubleday.

Rao, Z. Y. 饒宗頣 (1996). Zhongguo Shixue shang zhi Zhengtong lun 中國史學上之正統論. Shanghai: Yuandong chubanshe 远东出版社.

Wang, A. H. (2006). Cosmology and Political Culture in Early China. Cambridge: Cambridge University Press.

\section{Copyrights}

Copyright for this article is retained by the author(s), with first publication rights granted to the journal.

This is an open-access article distributed under the terms and conditions of the Creative Commons Attribution license (http://creativecommons.org/licenses/by/3.0/). 